\title{
State Responsibility for National and International Flight Safety: An Insight from Indonesia
}

Irma Halimah Hanafi ${ }^{*}$, Syamsuddin Muhammad Noor, Marcel Hendrapati, Juajir Sumardi

Faculty of Law, Hasanuddin University, South Sulawesi, Indonesia

DOI: $10.36348 /$ sijlcj.2020.v03i11.006

| Received: 01.11.2020 | Accepted: 09.11.2020 | Published: 16.11.2020

*Corresponding author: Irma Halimah Hanafi

\section{Abstract}

The rapid development of aviation in Indonesia is reflected in the increasing growth in the number of air transport passengers in Indonesia. However, various problem of aviation in Indonesia threaten the safety of aviation. The research is a normative legal research using statute, case, and conceptual approaches. The results show that the essence of the State responsibility in the flights in Indonesia is absolutely the State responsible for these activities it can be seen in the provisions of international and national law provisions. In the capacity of the State as a provider, the State that must provide all facilities related to aviation safety protection in Indonesia. As a provider, the State is responsible for all obligations to provide protection for all flight activities in order to achieve the desired aviation safety standard (zeroaccident). The State' responsibility for aviation accidents by auditing and supervision related to aviation activities, because aviation is an activity that is very high-tech and has strict rules and flight standards.

Keywords: Aircraft Accident; Aviation Safety; Legal Enforcement; State Responsibility.

Copyright ( $) 2020$ The Author(s): This is an open-access article distributed under the terms of the Creative Commons Attribution 4.0 International License (CC BY-NC 4.0) which permits unrestricted use, distribution, and reproduction in any medium for non-commercial use provided the original author and source are credited.

\section{INTRODUCTION}

Numerous and consecutive aircraft accidents combined with a consistent failure to meet international safety standards in Indonesia, namely from the International Civil Aviation Organization and the European Aviation Safety Agency have proven a nightmare for the country's aviation safety reputation $\left.{ }^{1}\right]$. Indonesia geographically is very strategic, if looked from the land, sea and air. The territory of Indonesia is between two continents and two oceans allow Indonesia to play a role in all aspects of the life of the international community $\left[{ }^{2}\right]$. Indonesia is a maritime country surrounded by oceans and airplanes as most appropriate solution to grow the economy $\left[{ }^{3}\right]$. Airplanes can connect remote and underdeveloped areas where

\footnotetext{
${ }^{1}$ Nugraha, R. (2016). Improving Aviation Safety in Indonesia: How Many More Accidents?. Hasanuddin Law Review, 2(3), 328-348. doi: http://dx.doi.org/10.20956/halrev.v2i3.321

${ }^{2}$ Moch. Isnaeni, (1996). Hipotek Pesawat Udara Di Indonesia, Surabaya, Dharma Muda, p.2

${ }^{3}$ Arimbi Bimoseno, Pesawat Habibie Sayap-Sayap Mimpi Indonesia, Jakarta, Kata Media, 2012, p. 93.
}

other transportation cannot reach. The strategic position it contains abundant natural resources in it $\left[{ }^{4}\right]$.

The uniqueness of Indonesian airspace becomes a controller of global air circulation and the formation of a world climate which is a strategic advantage of Indonesian airspace. It is said so because not all countries in the world have three regional dimensions. Some countries in the world only have two dimensions, namely land and air, and do not have a sea dimension. The existence of land and sea areas causes Indonesia airspace to be also broad compared to other countries in the world. The total area of Indonesian air sovereignty is $5.193 .252 \mathrm{~km}^{2}$, FIR (flight information region) is $4.110 .752 \mathrm{~km}^{2}$, and aircraft movements are 9887/day $\left[{ }^{5}\right]$.

\footnotetext{
${ }^{4}$ Untung Suropati et al, Indonesia INC. Peta Jalan Menuju Poros Maritim Dunia, Jakarta, Elex Media Komputindo, 2018 p. 264

${ }^{5}$ Endang Puji Lestari, Politik Hukum Navigasi Penerbangan. Konsep Penyelenggaraan Navigasi Penerbangan Dalam Perspektif Hukum Udara Internasional Dan Nasional, Malang, Setara Press, 2018, p. 8
} 
The rapid development of aviation in Indonesia is reflected in the increasing growth in the number of air transport passengers in Indonesia [ $\left.{ }^{6}\right]$. In 2017 , the arrival of aircraft with domestic flights was 972.9 thousand units, with a total passenger of 95.4 million people $\left[{ }^{7}\right]$. A vast airspace of Indonesia with many national and international aviation activities has the potential to be prone to air accidents and can pose a threat of violating Indonesia airspace. The threat of violating airspace, in addition disturbing national security related to aviation activities, it is also affects territorial sovereignty when viewed from the aspect of national defense. The possibilities that occur during flight activities include: unidentified aircraft, consisting of aircraft deemed deviating from their path or aircraft that are reported to be operating in a certain area but do not provide their identity to the air traffic service, ATC (Air Traffic Control). The deviate aircraft could be suspected of being hijacked $\left[{ }^{8}\right]$. A website AviationSafety noted that there were 318 collisions in the air in the form of flight accidents where two or more planes touched while flying (mid-air collision) and thousands of times near miss incidents namely conditions or situations where the accident almost occurred from 1922 to 2015 , both for civilian or military aviation [ $\left.{ }^{9}\right]$.

Indonesia is listed as a country with the highest fatal aviation accidents in Asia. Between 1945 and 2018, there were 99 fatal commercial aircraft accidents with a total of 2.224 victims. All these calamities reduce the credibility, professionalism and competence of managing the civil aviation industry, but also regulators and all stakeholders $\left[{ }^{10}\right]$. Fatal accident suffered by Indonesian airline Lion Air flight number LNI-601. Lion Air obtained an IOSA certificate from IATA on 13 March 2017, but had a fatal accident 1 year 7 months later in 2018. IOSA audits are periodic (renewal), meaning that IATA will repeatedly conduct. Meanwhile, ICAO describes the condition of accidents

6 Ministry of Transportation of the Republik Indonesia. Biro Komunikasi dan Infirmasi Publik, Kapasitas Dan Kualitas Bandara Di Indonesia Perlu Ditingkatkan, http://dephub.go.id/beta2017/post/read/kapasitas-dankualitas-bandara-di-indonesia perlu-ditingkatkan.

${ }^{7}$ Statistik Transportasi Udara, Air Transportation Statistics 2017. Katalog: 8303003. Indonesian Central Bureau of Statistics. P.18

${ }^{8}$ Civil Aviation Safety Regulations Section 170 Air Traffic Regulations. 170,024.

${ }^{9}$ Rizky Tyas Febriani, Lalu Lintas Udara Semakin Padat, Ternyata Begini Cara Menghindari Tabrakan Pesawat Saat Terbang, http://travel.tribunnews.com/2017/12/04/lalu-lintasudara-semakin-padat-ternyata-begini-cara-menghindaritabrakan-pesawat-saat-terbang?page=all

10 Ninok Leksono, Memulihkan Optimisme Penerbangan, www.kompas.id. Published on Friday 2 November 2018. and deaths from Indonesia that occurred in the 20082018 period.

For 15 fatal accidents in 2018, that recorded by the Aviation Safety Network, 3 fatal accidents were experienced by airlines that were blacklisted by the European Union, and there were 2 countries whose airlines had fatal accidents with more than 100 victims, namely Cuba and Indonesia. Airlines that are included in the blacklist will not pass the IATA's audit or if they are already members, they will be removed from the member group to be re-tested first. The standard parameters used in the IOSA's test are SARPs from ICAO [ $\left.{ }^{11}\right]$. Aviation safety in Indonesia is the responsibility of all elements both directly and indirectly, including regulators, operators, manufacturers, users and other activities related to aviation. However, the existence of responsibility needs to be realized, one way is by the existence of policies in the form of regulations by the government and its agencies on flights.

Various problem of aviation in Indonesia threaten the safety of aviation. Important thing related to aviation safety is flight traffic guidance $\left[{ }^{12}\right]$ and limited to the apparatus whose tasks and responsibilities are in the field of national defense. Air traffic information in the form of: $\left[{ }^{13}\right]$ information relating to the movement of each aircraft or other forms of information service and up-to-date information according to the current situation of each aircraft; information on the position of each aircraft in relation to other aircraft; issue permits and information for the purpose of preventing collisions between aircraft under control and accelerating and maintaining control of air traffic; coordinate between other units.

Air space is a sovereign territory becomes the responsibility of the State and is given authority to the government. For Indonesia, this has become a basic principle as mandated in the 1945 constitution. Therefore, the government holds the rights and obligations for activities and business carried out in the national airspace $\left[{ }^{14}\right]$, including creating national legal

\footnotetext{
${ }^{11}$ International Civil Aviation Organization - Jejak Keselamatan Di Tahun 2018. https://www.indonesiaicao.org

${ }^{12}$ A prohibited area is an air area with permanent and comprehensive restrictions for all aircraft. Restrictions can only be set in Indonesian territory, for example a nuclear installation or a presidential palace. This provision is contained in the explanation of article 7, paragraph 1 of Act No. 1 of 2009 concerning Aviation.

${ }^{13}$ Section 170.033, Air Traffic Regulations

14 Chapter II Konsepsi Pengaturan Pengelolaan Ruang Udara Nasional, through internethttp://ruu.lapan.go.id/doc/bab2.pdf
} 
rules protecting aviation activities in order to create flight safety.

\section{METHOD OF RESEARCH}

The research is a normative legal research using statute, case, and conceptual approaches. It was conducted by identifying basic legal principles in solving air law problems related to aviation activities carried out in Indonesian territory. It was conducted in several places in Indonesia, namely PT Industri Pesawat Terbang Nurtanio (IPTN) Bandung; Director General of Civil Aviation and ATCs East Indonesia.

\section{State Responsibility in Aviation in Indonesia}

In legal references, responsibility is often used in 2 (two) interchangeable terms, namely responsibility and liability $\left[{ }^{15}\right]$ In international settings, understanding of responsibility and liability is very important, given the difference in meaning between the legal regime of responsibility that applies under general international law $\left[{ }^{16}\right]$ and space law. In addition, this regime is also related to the consequences of the countries that are needed both in the international and national realms. Countries bear a significant burden on the international arena which in turn dictates the need to manage and deal with all their consequences at the national level.

The provision of liability are important not for the developed countries of space (non-space faring nations) to ensure that they will be compensated for any damage. This is evident from Salmond's definition which distinguishes between the 2 (two) terms by saying that responsibility or liability is linked to the existing needs of the wrongdoer and the correction of the wrong. The difference between State responsibility and liability lies in the fact that the prerequisite for responsibility is an act of violating international law and liability is a dangerous effect of an activity, which is not a mere violation of international law $\left[{ }^{17}\right]$. ${ }^{15}$ Frans G, von der Dunk., 1991, Liability Versus
Responsibility In Space Law: Misconception or
Misconstruction?, Law, College of Space and
Telecommunications Law Program Faculty Publications, University of Nebraska - Lincoln Year. Quoted in Mardianis. Application of State Responsibility in Regulating the Implementation of Act No. 21 of 2013 for Third Party Losses. Center for Aerospace Studies and Information, National Institute of Aeronautics and Space. Jurnal Kajian Kebijakan dan Hukum Kedirgantaraan, p. 8

${ }^{16}$ Maskun, M., \& Ramli, R. (2018). A New Treaty for Fully Autonomous Weapons: A Need or a Want?.Hasanuddin Law Review, 4(1), 54-67. doi:http://dx.doi.org/10.20956/halrev.v4i1.1300

${ }^{17}$ Bin Cheng. International Responsibility National Activities and the Appropriate State. Article VI of the 1967 Space Treaty Revisited. 1998. Journal Space Law 26 (1). In Mardianis. Application of State
In the capacity of the State as a provider, the State must provide all facilities related to aviation safety protection in Indonesia. As a provider, the State is responsible for all obligations to provide protection for all flight activities in order to achieve the desired aviation safety standard (zero-accident) $\left[{ }^{18}\right]$. The State is responsible for and guarantees a minimum standard of overall aviation safety. The State as the regulator, the State establishes the rules of state life $\left[{ }^{19}\right]$ including rules on aviation. The government, in this case the State makes various regulations and policies relating to aviation safety protection activities.

The State as umpire (referee), to set fair standards for parties engaged in the aviation sector, especially between the public and private sectors or between aviation business fields with one another. Article 1 of the 1944 Chicago Convention "the contracting states, recognize that every state has complete and exclusive sovereignty over the airspace above its territory" the countries that signed the Chicago Convention recognize that each State has complete and full sovereignty over the airspace over its territory $\left[{ }^{20}\right]$. This convention implies that the State has sovereignty for airspace over the territory of the State. With this sovereignty, it has responsibility for all activities carried out in its airspace as well as other activities related to activities in the air, starting from the time the aircraft is at the airport, when flying and arriving at the destination airport. The State is responsible for all flight activities in order to achieve aviation safety.

International regulations on aviation, namely the 1944 Chicago Convention, article 28 indicate how the responsibility of State is related to air flight facilities and systems in order to create aviation safety. Article 28 of the 1944 Chicago Convention on International Civil Aviation: "each contracting state undertakes, so far it a find practicable, to: a). Provide, in its territory, airports, radio services, meteorological services and other air navigation facilities to facility international air navigation, in accordance with the standards and practices recommended or established from time to time, pursuant to this convention. $b$ ). Adopt

Responsibility in Regulating the Implementation of Act No. 21 of 2013 for Third Party Losses. Center for Aerospace Studies and Information, National Institute of Aeronautics and Space. Jurnal Kajian Kebijakan dan Hukum Kedirgantaraan, p. 89

18 J. G. Starke, Pengantar Hukum internasional, Bandung, Justitia Study Group, 1986, p.163.

${ }^{19}$ Magassing, A., Patittingi, F., Alwy, S., Hambali, R., Sumardi, J., Kadarudin, \& Hendrapati, M. (2018). The removal of offshore installation in indonesian national regulation. Journal of East Asia and International Law, 11(1), 183-192. doi:10.14330/jeail.2018.11.1.09

${ }^{20}$ Article 2, Chicago Convention 1944. 
and put into operation the appropriate standard systems of communications procedure, codes, markings, signals, lighting and other operational practices and rules which may be recommended or established from time to time, pursuant to this convention. c). Collaborate in international measures to secure the publication of aeronautical maps and charts in accordance with standards which may be recommended or established from time to time, pursuant to this convention $\left[{ }^{21}\right]$ ".

This provision is related to aviation safety, this is because aircraft passing over the airspace require guidance from the ground by an air traffic controller officer. The country through which an aircraft passes is obliged to provide flight guidance services. Guidance services serve as safe and secure flight operations, in addition to ground services such as airports and weather information. Providing services equipped with good facilities is absolutely necessary $\left[{ }^{22}\right]$.

\section{State's Responsibility in Supervision of Aviation Operators}

Operator is person or legal entities that operate aircraft either commercially (airlines) or noncommercially (general aviation) $\left[{ }^{23}\right]$. Achievement of aviation safety levels can be achieved by the functioning of all system components in the aviation industry consisting of airport operators, airline operators, air traffic operators and aircraft maintenance operators, as well as regulations set by regulators $\left[{ }^{24}\right]$. In this paper, the operator in question is more focused on operators in the sense of airlines.

Nowadays, many airlines are one of the reasons for the increase in flight routes in Indonesian airspace, both national and international flight routes. Aviation in Indonesia regulates the routes that can be passed by aircraft. Domestic flight networks and routes for scheduled air transportation are determined by the minister and foreign flight route networks are stipulated by the minister based on international air transport

${ }^{21}$ Article 28, Chicago Convention 1944

${ }^{22}$ Dewa Gede Sudika Mangku, I Ketut Radiasta. Tanggung Jawab Negara terhadap Penembakan Pesawat MH17 berdasarkan Hukum Internasional. Jurnal Pandecta. Volume 14. Nomor 1. June 2019..

${ }^{23}$ Gerald G. E. F. The Protocol to Amend the Convention on Demage Caused by Foreign Aircraft to Third Parties on the Surface (Romen1952), dalam Nicolas Mateesco Matte Ed, Annals of Air and Space. Vol IV-1979) 11-28. Quoted on the footnote Dikutip dari catatan kaki of Martono. Hukum Angkutan Udara Berdasarkan Undang-undang RI No. 1 Tahun 2009. Rajawali Pers. Jakarta. P.228

${ }^{24}$ Eko Poerwanto \& Uyuunul Mauidzoh, Analisis Kecelakaan Penerbangan Di Indonesia Untuk Peningkatan Keselamatan Penerbangan. Jurnal Angkasa. Vol. 8, Nomor 2, November 2016, p.9 agreements $\left[{ }^{25}\right]$. Domestic flight route networks are established with consideration of requests for air transportation services, fulfillment of technical requirements for flight operations, airport facilities in accordance with aviation safety and security provisions, services for all areas that have airports, the center for flight operations of each air transport agency scheduled commerce and integration of domestic and foreign routes. Meanwhile, foreign flight networks and routes are determined by taking into account national interests, demand for air transport services, tourism development, industrial and trade potential, regional economic potential and intra and intermodal integration $\left[{ }^{26}\right]$.

In the aviation industry, airplanes are main core capital, with high prices it can be estimated how much funds are needed to manage an aviation business that requires not enough one or two airplane $\left[{ }^{27}\right]$. Every airplane manufactured by the factory remains registered with the factory country code (country of manufacture). After the transaction process between the manufacturer and the buyer has been completed, the registration is changed according to the buyer' country registration code, which is written on the back of the airplane. This registration will be printed on the aircraft, even if the airplane' life has been completed until it enters the museum or after it becomes a junk $\left[{ }^{28}\right]$.

One registration may not be used by another airplane, or a new airplane from the factory is not allowed to use a registration that has been used by first airplane. Facilitate search is necessity in the world of aviation in an effort to maintain security. Some countries enter into an agreement or bilateral agreement that they will not allow an airline to land at the airport of their respective country if that airline uses an aircraft with the registration of another country $\left[{ }^{29}\right]$.

Compliance with international aviation standards is a fundamental aspect, there are approximately 10.000 standards and 40,000 quasistandards listed in annex 1-19 ICAO along with documents and circular. If a country has never sent differences to ICAO, it means that country must comply

${ }^{25}$ Article 122 paragraphs 1 and 2 of Act No. 1 of 2009 on Aviation

${ }^{26}$ Article 122 paragraphs 1 and 2 of Act No. 1 of 2009 on Aviation, Article 4 paragraph 2. Regulation of the Minister of Transportation No. PM 88 of 2013 on Aviation Networks and Routes

27 Moch. Isnaeni, Hipotik Pesawat Udara Di Indonesia, CV Dharma Muda, 1996, p.156

28 Desmond Hutagaol, Pengantar Penerbangan Perspektif Profesional, Jakarta, Penerbit Erlangga, 2013, p.18

${ }^{29}$ Bakhtiar, H. S., Dhanur, N. A., Ashri, M., \& Hendrapati, M. (2016). Air Defence Identification Zone (ADIZ) in International Law Perspective. JL Pol'y \& Globalization, 56, 16. 
with all standards made by ICAO. Indonesia is a country that has never sent a difference document to ICAO means that Indonesia must comply with all standards set by ICAO $\left[{ }^{30}\right]$. If a country cannot comply with certain articles contained in the annex, that country must immediately explain the differences between their country practice and the practice set by international standards and immediately notify ICAO, sixty days before the standards or terms of ICAO apply $\left[{ }^{31}\right]$. To know the compliance of State with the established aviation standards, ICAO established a Universal Safety Oversight Safety Audit (USOAP) program $\left[{ }^{32}\right]$.

ICAO's aviation policies are contained in Annex 1 - 19, which regulates technical and operational aspects of international civil aviation, for example the flightworthiness of an airplane, control of aircraft traffic, telecommunications, aviation safety and so on, make international flights safer, more reliable and more practical $\left[{ }^{33}\right]$.

International standards and recommended practices with respect to minimum operations are based on the aircraft and environmental factors found at each airport. Subject to operator approval, the aircraft operator must consider the type of aircraft or helicopter, the level of modern equipment carried on the aircraft, the characteristics of the approach and runway aids and the operating skills of the crew in carrying out the procedures involved in operations in all weather conditions.

Another development is the introduction of provisions (commonly referred to as ETOPS) to ensure safe operation by twin-engine aircraft operating over a wide range, often over water. This type of operation has emerged due to the attractive economy of the twinengine aircraft that are now available $\left[{ }^{34}\right]$.

Pilot-in-command has final responsibility to ensure that flight preparation is complete and complies with all requirements and is required to certify flight preparation forms that the aircraft is airworthy, and that other criteria are met with regard to instrument maintenance, mass distribution and payload (and cargo safeguards), and the limitations of aircraft operation.

30 Yaddy Supriyadi, Keselamatan Penerbangan Teori dan Problematika, Jakarta, Telaga Ilmu Indonesia, 2012, p.6

${ }^{31}$ Article 38, Convention Chicago 1944

${ }^{32}$ Meanwhile, for security audits, ICAO created the Universal Security Audit Program (USAP).

${ }^{33}$ Ini Putu Anggraeni. Convention On Internasional Civil Aviation. Indonesian Journal Of International Law. Volume 6 Nomor 4 Juli 2009. hlm 565. http://ijil.ui.ac.id/ index.php/home/article/view/492/pdf_376 34 ibid
Another important aspect is the terms for operators to establish rules limiting flight times and flight duty periods for crew members. The same standards also require operators to provide adequate rest periods so that fatigue occurring either on flights, or consecutive flights over a specified period of time, does not compromise flight safety. The alert flight crew must be able to deal not only with any technical emergency, but with other crew members and must react properly and efficiently based on the evacuation of the aircraft. These rules must be entered in manual operation manually.

Important for safe aircraft operation is knowledge of the operating limits of each type of aircraft. Annex six establishes minimum operating performance limits, with respect to the aircraft used. These standards take into account factors that can affect the performance of different types of aircraft: aircraft mass, altitude, temperature, weather conditions and runway conditions, and include take-off and landing speed in conditions involving failure of one or more power units. Detailed examples are provided in Annex C Annex six, Part I, where performance levels have been calculated and found to apply to a wide range of aircraft characteristics and atmospheric conditions.

Aviation is part of the national transportation system which has the characteristics of being able to move in a fast time, using high technology, capitalintensive, reliable management, and requires optimal safety and security guarantees, it is necessary to develop its potential and role that is effective and efficient, and helps to create steady and dynamic national distribution pattern $\left[{ }^{35}\right]$. Flight is a condition where safety requirements are met in the use of airspace, aircraft, airports, air transportation, flight navigation, and other supporting facilities and public facilities $\left[{ }^{36}\right]$. Aviation safety is a condition where safety requirements are met in the use of airspace, aircraft, airports, air transportation, flight navigation, as well as other supporting facilities and public facilities $\left[{ }^{37}\right]$.

In Indonesia, aviation activities are generally regulated in Act No. 1 of 2009 concerning Aviation. Ensuring national aviation safety, the minister in charge of establishing a national aviation safety program (State safety program). The national aviation safety program aims to improve the ability of the government and aviation service providers to achieve standards of safety, service, technology and human resource competence in aviation service providers. One part of

${ }^{35}$ Consideration of Act No. 1 of 2009 on Aviation

36 Government Regulation of the Republic of Indonesia No. 4 of 2018 concerning Security of the Airspace of the Republic of Indonesia, Article 1 point 5

${ }^{37}$ Act No. 1 of 2009 concerning Aviation, Article 1 point 48

(c) 2020 | Published by Scholars Middle East Publishers, Dubai, United Arab Emirates 
the reform measures implemented by the government is establishing the National Aviation Safety Program $\left[{ }^{38}\right]$. It can be concluded that in aviation activities the state is also responsible for creating aviation safety, because flight safety is not only the responsibility of the flight operator. The form of State accountability through the relevant agencies makes all efforts in terms of creating aviation safety.

One aspect of aviation safety is provision regarding aircraft accident investigations. An aircraft accident investigation is absolutely necessary because from the results of an aircraft accident investigation, various kinds of findings can be obtained that can provide an overview of the causes of an aircraft accident to be studied by various parties related to the world of aviation and made improvements to support aviation safety. From many studies and the results of investigations on the causes of aircraft accidents in Indonesia, what really stands out is negligence or carelessness which leads to weak supervisory factors.

In the world of aviation that uses high technology and high discipline is required without compromise in complying with applicable rules, regulations and regulations $\left[{ }^{39}\right]$. Every flight accident must be analyzed and then established aircraft accident prevention measures $\left[{ }^{40}\right]$. This policy is set based on the paradigm that airplane accidents are the accumulation of incidents that are left unchecked. In theory is said that 600 incidents will be 30 ordinary accidents, 20 serious accidents and 1 fatal accident. Every airplane incident must be investigated with the aim not to blame but to be used as learning material in order to prevent similar accidents from happening again, thus the success of preventing airplane accidents is very dependent on incident reporting $\left[{ }^{41}\right]$.

In Indonesia, the release of Aviation Accident Investigation Data for 2010-2016 states that the main causes of aviation accidents occur due to human factors $(67.12 \%)$. Apart from human factors, there are several other contributing factors that are a factor in aviation accidents but the percentage is small. Technical factors, for example, accounted for 15.75 percent of accidents. Environmental factors 12.33 percent of cases $\left[{ }^{42}\right]$.

The factor of human error confirms that sophisticated and up-to-date equipment does not guarantee zero accidents in flight. The case of Adam

\footnotetext{
${ }^{38}$ National Aviation Safety Program R.I. Chapter II. 2.1.p. 6. www.bphn.go.id

${ }^{39}$ Chappy Hakim, Tol Udara Indonesia. Jakarta: Kompas Gramedia, 2018, p.70.

${ }^{40}$ Doc. 9422 Accident Prevention Manual ICAO

${ }^{41}$ Yaddy Supriyadi, op.cit. p.11

${ }^{42}$ Frendy Kurniawan, Kecelakaan Lion Air \& Teror Kerapnya Kecelakaan Pesawat Terbang.
} https://tirto.id/c8Qt
Air plane that crashed in West Sulawesi waters in 2007 can be used as evidence. The results of the investigation of KNKT gave the final conclusion that the cause of the accident was pilot error. Reports said the plane that ended in the sea comes from the negligence of the two aircraft pilots. The aircraft had lost control due to an incorrectly coded automatic control instrument code. Initially, they attempted to repair the damage to the navigation system or IRS. The human factor is increasingly important considering the types of airplane accidents.

KNKT's records on 2017 for all types of aircraft accidents, runway excursions (38.89\%) were main contributor on technical factors (system/component failure or non-power plant malfunction, controlled flight into terrain, and others). A runway excursion is a situation where an aircraft experiences a runway exit event. Psychology professor James Reason said that $90 \%$ of the factors that cause aviation accidents are humans. For example, when the co-pilot does not dare to take the decision to take over the duties of the pilot captain, it could result in a fatal accident. Advances in technology can minimize human performance and the existence of clear collaborative management between cockpit crew makes the number of flight accidents reduced.

A number of investigations related to aircraft accidents stated that the aircraft accidents in the world was due to full schedule of commercial flight, poorly trained pilots who followed inefficient and outdated safety rules and procedures, and some of them stated that there was a role as a controller for the incident, either due to the lack of or slow communication between the pilot and the air traffic controller, air traffic congestion $\left[{ }^{43}\right]$. One of the online news media, Deutsche Welle, published the results of direct interviews with several former pilots with experience crossing the region in Southeast Asia and said that the congestion of flight traffic in Indonesia often forces pilots to take unnecessary risks to stick to their travel schedule. They also complained about air traffic control technology in Indonesia that is outdated and deserves to be replaced as well as the performance of Indonesian aviation supervisors who are overwhelmed in handling flight traffic in congested Southeast Asian airspace. Dense air traffic makes the role of Air Traffic Controller officers in carrying out their duties demanding a high degree of discipline, focus and responsibility.
${ }^{43}$ Lalu Muhammad Saleh, K3 Penerbangan: Sebuah Kajian Keselamatan Dan Kesehatan Kerja Pada Karyawan Air Traffic Controller (ATC), Yogyakarta Deepublish Publisher, 2017, pp.5-6 


\section{CONCLUSION}

The essence of the State responsibility in the flights in Indonesia is absolutely the State responsible for these activities it can be seen in the provisions of international and national law provisions. In the capacity of the State as a provider, the State that must provide all facilities related to aviation safety protection in Indonesia. As a provider, the State is responsible for all obligations to provide protection for all flight activities in order to achieve the desired aviation safety standard (zero-accident). The State' responsibility for aviation accidents by auditing and supervision related to aviation activities, because aviation is an activity that is very high-tech and has strict rules and procedures. Although compliance with aviation standards is not an absolute guarantee of non-occurrence of accidents, flights will be very dangerous if they are not managed according to established flight standards. 